\title{
PENGEMBANGAN BAHAN AJAR KALKULUS PEUBAH BANYAK BERBANTUAN SOFTWARE GEOGEBRA BAGI MAHASISWA PENDIDIKAN MATEMATIKA
}

\author{
Annajmi $^{1)}$; Ratri Isharyadi $^{2)}$ \\ ${ }^{1 .}$ Universitas Pasir Pengaraian; annajminajmi86@gmail.com. \\ ${ }^{2}$ Universitas Pasir Penagraian; arya math@ymail.com
}

\begin{abstract}
Variable calculus is a subject that requires students to have high mastery and competence. This is because the material presented requires students to think critically and creatively to solve problems. In fact the results of the previous semester's assessment analysis, the percentage of students who graduated with grades A or B was very low. The research method is research and development, with ADDIE development stages, namely Analysis, Design, Development, Implementation, and Evaluation. The results of the needs analysis showed that students need teaching material for calculus variable which is assisted by a technology of mathematical applications, where students' opinions on the need for a mathematical application such as geogebra software in learning, there are $66.7 \%$ of students strongly agree, and there are $33.3 \%$ agree. The validation results show that the average of all aspects of the assessment of teaching materials obtained an average of 4.29 means that the teaching materials are valid. The results of the practicality questionnaire analysis of the 20 students who took the lecture obtained an overall average of 4.28, which means practical. The results of student responses to the teaching material questionnaire from the aspects of teaching materials and learning activities obtained an average percentage of total positive responses of students amounted to $81.67 \%$ meaning that teaching materials are effectively used by students in learning.
\end{abstract}

Keywords: teaching material; calculus of many variables; geogebra

\begin{abstract}
ABSTRAK
Kalkulus peubah banyak merupakan mata kuliah yang mengharuskan mahasiswa memiliki penguasaan dan kompetensi yang tinggi. Hal ini dikarenakan materi yang disajikan menuntut mahasiswa berpikir kritis dan kreatif melakukan pemecahan masalah. Kenyataannya hasil analisis penilaian semester sebelumnya, persentase mahasiswa yang lulus dengan nilai A atau B sangat rendah. Metode penelitian adalah penelitian dan pengembangan, dengan tahapan pengembangan ADDIE, yaitu Analysis, Design,Development, Implementation, dan Evaluation. Hasil analisis kebutuhan diperoleh bahwa mahasiswa memerlukan bahan ajar kalkulus peubah banyak yang berbantuan suatu teknologi dari aplikasi matematika, dimana pendapat mahasiswa terhadap keperluan suatu aplikasi matematika seperti software geogebra dalam pembelajaran, terdapat $66,7 \%$ mahasiswa sangat setuju, dan terdapat $33,3 \%$ setuju. Hasil validasi menunjukkan bahwa rata-rata dari keseluruhan aspek penilaian terhadap bahan ajar diperoleh rata-rata 4,29 artinya bahan ajar telah valid. Hasil analisis angket praktikalitas dari 20 orang mahasiswa yang mengikuti perkuliahan diperoleh rata-rata keseluruhan yaitu 4,28yang artinya praktis. Hasil angket respon mahassiwa terhadap bahan ajar dari aspek komponen bahan ajar dan kegiatan pembelajaran diperoleh persentase rerata total respon positif mahasiswa sebesar $81,67 \%$ artinyabahan ajar efektif digunakan oleh mahasiswa dalam pembelajaran
\end{abstract}

Keywords: bahan ajar; kalkulus peubah banyak; geogebra 
Jurnal IImu Pendidikan Indonesia 8 (1) : 46 - 55 | 47

\section{PENDAHULUAN}

Kalkulus peubah banyak merupakan mata kuliah lanjutan dari kalkulus diferensial dan kalkulus integral. Mata kuliah ini juga menjadi prasyarat untuk mengikuti mata kuliah persamaan differensial dan statistik matematika. (Widiyantp, 2010) mengungkapkan bahwa Kalkulus Peubah Banyak (KPB) dalam perkuliahan Kalkulus I dan Kalkulus II umumnya membahas satu peubah dalam ruang satu dimensi atau dua dimensi, dalam KPB membahas lebih dari satu peubah dalam ruang tiga dimensi. Oleh karena itu mahasiswa harus memiliki penguasaan yang tinggi terhadap mata kuliah ini, selain itu mahasiswa harus memiliki kemampuan berpikir tingkat lanjut dan penguasaan yang mendalam terhadap materi pada mata kuliah ini. Mahasiswa yang mengikuti mata kuliah kalkulus peubah banyak, diharuskan bisa berpikir abstrak dan berpikir kritis dalam melakukan pemecahan masalah.

Berdasarkan hasil analisis penilaian pada semester sebelumnya TA 2017/2018, hasil analisis terhadap hasil ujian akhir semester, diperoleh fakta bahwa mahasiswa gagal dalam menyelesaikan soal yang diberikan, persentase mahasiswa yang lulus dengan nilai yang bagus (A atau B) masih sangat rendah, yaitu masih dibawah 50\% dari jumlah siswa. Hasil ini belum optimal dan harusnya hasil tersebut bisa lebih baik. Hal ini terjadi karena materi yang disajikan menuntut mahasiswa mampu berpikir kritis dan kreatif dalam melakukan pemecahan masalah yang berkaitan dengan grafik persamaan dalam ruang dimensi tiga, fungsi dua peubah atau lebih dan grafik fungsi. Hasil refleksi peneliti sebagai pengampu pada tahun akademik 2017/2018, penyebab belum optimalnya prestasi belajar mahasiswa adalah: a) sebagai pengampu mata kuliah, peneliti telah memberikan kesempatan kepada mahasiswa untuk mendiskusikan kesulitan yang dihadapi dalam perkuliahan, namun kesempatan tersebut sedikit mahasiswa yang memanfaatkannya; b) perkuliahan belum menggunakan buku ajar buatan sendiri dan mahasiswa hanya mengandalkan satu buku teks. Selain itu hanya sebagian kecil mahasiswa yang memiliki buku teks, sebagian besar lainnya hanya belajar dari materi yang disampaikan dosen baik secara langsung maupun melalui slide power point. Mahasiswa mengalami kesulitan memahami materi perkuliahan. Sulitnya memahami materi Kalkulus Peubah Banyak karena kurang didukung oleh sumber belajar dan metode yang bervariasi. Berkaitan dengan itu perlu dikembangkan bahan ajar. Menurut Reza, dkk (Irawati dan Saifuddin, 2018) bahwa bahan ajar merupakan salah satu komponen yang dapat membantu 
kelancaran belajar siswa maupun

mahasiswa. Selain itu (Ebit Rusali 2019) juga menjelaskankan bahwa pengembangan bahan ajar dapat dijadikan salah satu solusi untuk mengatasi kesulitan dalam pemecahan masalah matematika.

Bahan ajar yang dimaksud dapat berupa buku teks, modul ataupun menggunakan media yang berbasis teknologi berbantuan aplikasi komputer, sebagaimana yang dinyatakan oleh Yusta (Fitriyah, Santoso dan Suryadinata, 2018) bahwa untuk penyediaan bahan ajar, perangkat pembelajaran, media pembelajaran berbantu komputer untuk meningkatkan pembelajaran matematika yang lebih efektif.

Media pembelajaran berbantu komputer sudah banyak tersedia saat ini, baik yang berbayar ataupun gratis. Penggunaan software juga dapat membantu siswa dalam memahami konsep-konsep geometri yang bersifat abstrak, karena software tersebut dapat merepresentasikan bangun-bangun geometri yang bersifat abstrak maupun bangun datar segi empat. Belajar dengan bantuan software, beberapa konsep matematika seperti volume benda putar, konsep limit, dan geometri dengan mudah dapat diterangkan dan bukti-bukti matematika disajikan dengan lebih menarik (Setiawati, 2014).

Aplikasi komputer seperti software geogebra merupakan satu dari beberapa aplikasi yang ada. Software ini dapat membantu mahasiswa dalam memvisualisasikan bentuk kurva ataupun persamaan aljabar dalam bidang kartesius dimensi dua dan tiga, grafik fungsi pada ruang dimensi tiga. Software geogebra dirancang oleh Markus Hohenwater tahun 2001/2002. Program ini merupakan open source, sehingga dapat diakses secara gratis. Software ini terdiri dari gabungan dua kajian matematika yang geometri dan aljabar, sehingga dapat dengan mudah menampilkan bentuk dari suaru kurva dan persamaan aljabar.

Hohenwarter dan Fuchs, (2004) Geogebra merupakan software serbaguna untuk pembelajaran matematika di sekolah menengah. Geogebra dapat dimanfaatkan sebagai media demontrasi dan visualisasi, alat bantu kontruksi, alat bantu penemuan konsep matematika, dan untuk menyiapkan bahan-bahan pengajaran.

Penggabungan suatu bahan ajar berupa buku teks dengan aplikasi geogebra menjadikan daya motivasi bagi mahasiswa untuk belajar, selain itu dapat membantu mahasiswa dengan mudah meningkatkan kompetensinya dalam mempelajari materi pada kalkulus peubah banyak.Berkaitan dengan itu tujuan dari penelitian ini adalah menghasilkan bahan ajar kalkulus peubah banyak berbantuan software geogebra valid, praktis dan efektif bagi mahasiswa pendidikan matematika Universitas Pasir Pengaraian 


\section{METODE PENELITIAN}

Jenis Penelitian ini adalah penelitian pengembangan (depelopment research). Model pengembangan yang digunakan mengikuti tahapan pengembangan ADDIE yaitu Analysis, Design, Development, Implementation, dan Evaluation.Tahap analisis meliputi mengidentifikasi kurikulum diantaranya CMPK dan Sub CPMK dari mata kuliah serta analisis kebutuhan. Tahap perancangan meliputi penentuan format, dan perancangan awal bahan ajar sesuai dengan sub CPMK yang ditentukam.Tahap pengembangan meliputi validasi oleh validator, analisis hasil validasi dari validator, revisi hasil validasi, sehingga diperoleh draft bahan ajar. Tahap Implementasi meliputi melakukan uji coba draft buku ajar pada subjek penelitian yaitu mahasiswa semester ganjil tahun akademik 2019/2020 pendidikan matematika Universitas Pasir Pengaraian yang mengambil mata kuliah Kalkulus Peubah Banyak. Tahap evaluasi yaitu memberikan memberikan angket respon dan angket praktikalitas terhadap produk bahan ajar yang dikembangkan untuk mengetahui efektifitas bahan ajar dalam perkuliahan.

Pengumpulan data menggunakan lembar validasi, lembar angket praktikalitas, lembar angket respon mahasiswa. Data yang telah dikumpulkan selanjutnya dilakukan analisis secara deskriptif, yaitu Analisis Validasi yang didasarkan pada pendapat tiga orang ahli dalam bidang pendidikan matematika.

Hasil validasi yang diperoleh selanjutnya diintrepesasikan berdasarkan Sinaga (Yuliani dan Saragih, 2015) yaitu.

$$
\begin{array}{r}
1 \leq \mathrm{Va}<2 \\
2 \leq \mathrm{Va}<3 \\
3 \leq \mathrm{Va}<4 \\
4 \leq \mathrm{Va}<5 \\
\mathrm{Va}=5
\end{array}
$$$$
\text { tidak valid }
$$
kurang valid cukup valid valid sangat valid

Analisis Praktikalitas, yaitu menggunakan angket praktikalita yang diberikan kepada mahasiswa diakhir ujicoba bahan ajar. Hasil praktikalitas ini yang diperoleh selanjutnya diintrepesasikan berdasarkan Sinaga (Yuliani dan Saragih, 2015) yaitu.

$$
\begin{array}{cl}
1 \leq \mathrm{Va}<2 & \text { tidak praktis } \\
2 \leq \mathrm{Va}<3 & \text { kurang praktis } \\
3 \leq \mathrm{Va}<4 & \text { cukup praktis } \\
4 \leq \mathrm{Va}<5 & \text { praktis } \\
\mathrm{Va}=5 & \text { sangat praktis }
\end{array}
$$

Analisis hasil angket respon mahasiswa terhadap bahan ajar yang digunakan di dalam pembelajaran meliputi respon positif dan respon negatif. Respon positif ditandai dengan pernyataanpernyataan positif seperti senang, baru, berminat terhadap komponen bahan ajar dan kegiatan pembelajaran, dan pernyataan negatif ditandai dengan pernyataanpernyataan seperti tidak senang, tidak baru dan tidak berminat dalam menggunakan komponen bahan ajar. 
Data yang diperoleh dari angket respon siswa dianalisis dengan menentukan persentase siswa yang memberi jawaban bernilai respon positif untuk setiap kategori yang ditanyakan dalam angket dengan menggunakan rumus Borich (Herman, 2012: 5) sebagai berikut :

$$
P R S=\frac{\sum A}{\sum B} \times 100 \%
$$

Keterangan :

PRS menyatakan Persentase banyak siswa yang memberikan respon positif terhadap setiap kategori yang ditanyakan, $\sum A$ menyatakan proporsi siswa yang memilih dan $\sum B$ menyatakan jumlah siswa (responden)

Pencapaian respon positif dari respons mahasiswa, dilihat apabila banyaknya mahasiswa memberi respon positif lebih besar atau sama dengan $80 \%$ dari banyak subjek yang diteliti pada saat uji coba (Sinaga, 2007: 171).

\section{HASIL DAN PEMBAHASAN}

Pelaksanaan penelitian ini berdasarkan tahapan pengembangan model ADDIE, yaitu Analysis, Design, Development, Implementation dan Evaluation. Adapun hasil pelaksanaan penelitian yang telah diperoleh, diuraikan secara deskriptif sebagai berikut

\section{Tahap Analysis}

Pada tahap ini dilakukan analisis kebutuhan bahan ajar dengan memberikan angket dan mengidentifikasi kurikulum diantaranya Capaian Pembelajaran Mata Kuliah (CPMK) dan Tujuan Pembelajaran dari mata kuliah.

a. Analisis Kebutuhan

Tahap ini dilakukan analisis kebutuhan bahan ajar dengan memberikan angket kepada mahasiswa yang telah pernah mengambil mata kuliah kalkulus peubah banyak. Responden adalah mahasiswa program studi pendidikan matematika semester lima Tahun Akademik 2019/2020 sebanyak 24 orang mahasiswa. Adapun hasil angket analisis kebutuhan yang telah dianalisis yaitu hasil analisis kebutuhan diperoleh bahwa mahasiswa memerlukan bahan ajar kalkulus peubah banyak yang berbantuan suatu teknologi dari aplikasi matematika, dimana pendapat mahasiswa terhadapkeperluan suatu aplikasi matematika seperti software geogebra dalam pembelajaran, terdapat $66,7 \%$ mahasiswa sangat setuju, dan terdapat $33,3 \%$ setuju.

b. Hasil Analisis Kurikulum

Tahap ini dilakukan analisis terhadap kurikulum, yaitu mengidentifikasi kurikulum diantaranya Capaian Pembelajaran Mata Kuliah (CPMK), Tujuan Pembelajaran dan Deskripsi Matakuliah. Adapun deskripsi matakuliah, CPMK dan tujuan pembelajaran yang akan disusun sebagai bahan ajar dari Kalkulus Peubah Banyak berbantuan Software Geogebra yaitu Deskripsi Mata kuliah. Mata kuliah kalkulus peubah banyak ini 
Jurnal IImu Pendidikan Indonesia 8 (1) : 46 - $55 \mid 51$

membahas tentang sistem koordinat, yang meliputi: sistem koordinat kutub, koordinat tabung, dan koordinat bola, dan hubungannya dengan koordinat cartesius, limit dan kekontinuan, ruang dimensi tiga, fungsi dua peubah atau lebih, turunan parsial, integral lipat dua, integral lipat tiga, integral lipat dua dua dalam koordinat kutub, integral lipat tiga dalam koordinat tabung dan bola.

Berdasarkan uraian deskripsi matakuliah, bahan ajar kalkulus peubah banyak berbantuan geogebra yang disusun meliputi Sistem Koordinat Kutub, Grafik Persamaan Kutub, Ruang Dimensi Tiga, Grafik Persamaan dalam Ruang Dimensi Tiga, Grafik Fungsi Dua Peubah dan Turunan Parsial.

Adapun materi prasyarat dalam mempelajari kalkulus peubah banyak ini, diantaranya sudah pernah mengikuti perkuliahan untuk mata kuliah Pengantar Dasar Matematika, Kalkulus Diferensial dan Kalkulus Integral.Adapun Capaian Pembelajaran Mata Kuliah (CPMK) dari mata kuliah ini, yaitu diharapkan

1. Mahasiswa mampu menjelaskan konsep sistem koordinat kutub, persamaan kutub, grafik persamaan kutub, ruang dimensi tiga, fungsi dua peubah atau lebih dan turunan parsial.

2. Menggambarkan suatu titik menggunakan koordinat kutub, grafik dari persamaan kutub, koordinat dalam ruang dimensi tiga, grafik dalam ruang dimensi tiga, grafik fungsi dua peubah atau lebih.

3. Menentukan turunan parsial dari suatu fungsi.

Tujuan Pembelajaran

Adapun tujuan pembelajaran dari perkuliahan ini yaitu

1. Mahasiswa mampu menjelaskan konsep sistem koordinat kutub, persamaan kutub dan grafik persamaan kutub.

2. Mahasiswa mampu menggambarkan koordinat kutub, grafik dari persamaan kutub.

3. Mahasiswa mampu menjelaskan konsep koordinat dalam ruang dimensi tiga.

4. Mahasiswa mampu menggambarkan koordinat dalam ruang dimensi tiga dan grafik persamaan dalam ruang dimensi tiga.

5. Mahasiswa mampu menjelaskan konsep fungsi dua peubah atau lebih, daerah asal dan daerah hasil.

6. Mahasiswa mampu membuat sketsa daerah asal, grafik persamaan kutub dan peta kontur/kurva ketinggian dari suatu fungsi dua peubah.

7. Mahasiswa mampu menentukan turunan parsial dari suatu fungsi.

Tahap Design

Tahap design ini meliputi penentuan format, dan perancangan awal bahan ajar 
sesuai dengan tujuan pembelajaran yang telah ditentukan.

a. Penentuan Format

Penentuan format meliputi, bentuk designcover dan tata letak materi yang disusun dalam bahan ajar. Bahan ajar disusun dalam bentuk buku ajar terdiri dari 5 Bab, masing-masing terdapat beberapa Sub Bab. Setiap Bab diawali dengan deskripsi singkat materi dan tujuan pembelajaran yang akan dicapai. Format bahan ajar disusun sesuai standar UNESCO yaitu kertas B5 ukuran $23 \mathrm{~cm} \times$ $15,5 \mathrm{~cm}$.

b. Rancangan Awal Bahan Ajar

Rancangan awal dari bahan ajar ini disusun sebagaimana tujuan pembelajaran dan format yang telah ditetapkan. Materi bahan ajar diketik menggunakan aplikasi pengolah kata yaitu Ms.Word versi 2013 dengan jenis huruf Time New Roman ukuran huruf 12. Materi disusun secara sistematis yang dilengkapi dengan langkah-langkah penggunaan Geogebra pada masing-masing materi disertai contoh dan soal-soal latihan disetiap akhir Bab. Bab pertama diawali pendahuluan menjelaskan deskripsi matakuliah, bab kedua pengenalan software geogebra dilanjutkan dengan materi perkuliahan.

Bahan ajar yang telah selesai disusun pada tahap awal ini, selanjutnya diberikan pada validator untuk diberikan penilaian atas kesesuaian aspek kurikulum, meliputi tujuan pembelajaran, cakupan materi, aspek bahasa, aspek penyajian, aspek media yang disajikan dalam bahan ajar.

\section{Tahap Development}

Tahap pengembangan meliputi validasi bahan ajar oleh validator, analisis hasil validasi dari validator, revisi bahan ajar sesuai hasil validasi, sehingga diperoleh draft bahan ajar yang siap untuk diujicobakan.

a. Hasil Analisis Validasi Bahan Ajar

Validasi ini didasarkan pada pendapat tiga orang ahli dalam bidang pendidikan matematika. Validasi dilakukan dengan melakukan penilai terhadap bahan ajar yang telah disusun berdasarkan lembar validasi yang berisi beberapa pernyataan terkait bahan ajar yang dikembangkan Berdasar pendapat ahli tersebut ditentukan rerata nilai untuk setiap aspek, sehingga diperoleh nilai rata-rata total aspek. Hasil validasi ini digunakan untuk revisi bahan ajar disajikan pada Tabel 1:

Tabel 1. Hasil Validasi Bahan Ajar.

\begin{tabular}{|l|c|}
\hline \multicolumn{1}{|c|}{ Aspek Penilaian } & $\begin{array}{c}\text { Rata- } \\
\text { Rata }\end{array}$ \\
\hline Aspek Kelayakan Isi & 4,5 \\
\hline Aspek Penyajian & 4,3 \\
\hline Aspek Bahasa & 4,2 \\
\hline Aspek Media & 4,5 \\
\hline $\begin{array}{l}\text { Aspek Keefektifan dari } \\
\text { Software Geogebra }\end{array}$ & 3,9 \\
\hline $\begin{array}{l}\text { Rata-Rata Keseluruhan } \\
\text { Aspek }\end{array}$ & $\mathbf{4 , 2 9}$ \\
\hline
\end{tabular}

Berdasarkan tabel 1 dapat dilihat bahwa rata-rata dari keseluruhan aspek penilaian terhadap bahan ajar ajar yang 
Jurnal IImu Pendidikan Indonesia 8 (1) : 46 - $55 \mid 53$

telah disusun diperoleh rata-rata 4,29 yang artinya bahan ajar telah valid. Bahan ajar tersebut dapat dilanjutkan pada tahap selanjutnya yaitu untuk diujicobakan pada mahasiswa dalam perkuliahan kalkulus peubah banyak.

\section{b. Revisi Bahan Ajar}

Hasil validasi menjadi dasar revisi bahan ajar dari komentar yang diberikan komentator pada lembar validasi. Secara umum komentar validator menyatakan bahan ajar sudah baik dan bisa digunakan pada tahap ujicoba. Beberapa bagian yang menjadi revisi yang dilakukan diantaranya terletak pada bahasa yang digunakan dalam bahan ajar dan tampilan gambar yang kurang jelas. Hasil revisi bahan ajar selanjutnya digunakan dalam tahap implementasi sebagai tahap ujicoba bahan ajar untuk mengetahui efektivitas dari bahan ajar yang telah disusun digunakan dalam pembelajaran.

\section{Tahap Implementation}

Tahap ini merupakan tahap uji coba dari draftbahan ajar yang telah dinyatakan valid dan hasil revisi berdasarkan komentar dari validator. Uji coba bahan ajar Kalkulus Peubah Banyak Berbantuan Software Geogebra ini dilaksanakan pada mahasiswa yang mengambil mata kuliah kalkulus peubah banyak semester ganjil tahun akademik 2019/2020 di Program Studi Pendidikan Matematika Universitas Pasir Pengaraian. Uji coba ini dilaksanakan pada bulan September 2019 sampai dengan Oktober 2019. Uji coba dilakukan pada pertemuan ketiga sampai dangan pertemuan keenam, selanjutnya dilakukan evaluasi terhadap bahan ajar.

\section{Tahap Evaluation}

Tahap ini dilakukan untuk mengetahui efektifitas dari penggunaan bahan ajar kalkulus peubah banyak berbantuan geogebra. Adapun yang dilakukan yaitu dengan memberikan angket praktikalitas dan angket respon.

a. Hasil Analisis Angket Praktikalitas

Angket ini bertujuan untuk mengetahui kepraktisan dari Bahan Ajar Kalkulus Peubah Banyak Berbantuan Geogebra yang telah disusun. Adapun yang dilihat diantaranya dari segi tampilan, bahasa serta kejelasan dan kemudahan dalam penggunaannya. Berdasarkan hasil analisis angket praktikalitas dari 20 orang mahasiswa yang mengikuti perkuliahan kalkulus lanjut diperoleh rata-rata keseluruhan yaitu 4,28 dengan demikian berada pada kategori praktis. Hal ini berarti Bahan Ajar Kalkulus Peubah Banyak Berbantuan Geogebra sudah dapat dikatakan praktis dan dapat digunakan dalam proses pembelajaran.

\section{b. Hasil Analisis Angket Respon}

Hasil analisis data angket respon mahasiswa terhadap komponen bahan ajar berbantuan geogebra dikatakan efektif apabila $\geq 80 \%$ mahasiswa memberikan 
respon positif terhadap bahan ajar dan kegiatan pembelajaran. Hasil analisis data respon mahasiswa diperoleh persentase rerata total respon positif mahasiswa sebesar $81,67 \%$. Hasil analisis ini dapat disimpulkan bahwa respon mahasiswa terhadap komponen dan kegiatan pembelajaran adalah telah efektif.

Berdasarkan tahapan penelitian dalam pengembangan bahan ajar kalkulus peubah banyak berbantuan geogebra diperoleh hasil bahwa bahan ajar tersebut memililiki validasi yang valid, begitupula untuk kepraktisan bahan ajar sebagaimana hasil angket praktikalitas diperoleh bahwa bahan ajar praktis, demikian juga dengan respon mahasiswa terhadap bahan ajar dari angket respon yang diberikan respon positif dengan senang dan berminat serta tertarik untuk belajar menggunakan bahan ajar kalkulus peubah banyak berbantuan geogebra. Hal ini menunjukkan bahwa bahan ajar yang dikembangkan dapat dinyatakan valid, praktis dan efektif untuk digunakan dalam perkuliahan.

\section{SIMPULAN DAN SARAN SIMPULAN}

Hasil validasimenunjukkan bahwa rata-rata dari keseluruhan aspek penilaian terhadap bahan ajardiperoleh rata-rata 4,29 artinya bahan ajar telah valid. Hasil analisis angket praktikalitas diperoleh ratarata keseluruhan yaitu 4,28 yang artinya praktis. Hasil angket respon mahasiwa terhadap bahan ajar dari aspek komponen bahan ajar dan kegiatan pembelajaran diperoleh persentase rerata total respon positif mahasiswa sebesar $81,67 \%$ artinya bahan ajar efektif digunakan oleh mahasiswa dalam pembelajaran.

\section{SARAN}

Berkaitan dengan itu disarankan kepada pembaca untuk menggunakan media berbasis teknologi khususnya software geogebra dalam pembelajaran matematika dan kepada peneliti lainnya dapat mengkaji lebih lanjut pemanfaatan bahan ajar berbantuan softwar geogebra atau aplikasi lainnya.

\section{UCAPAN TERIMA KASIH}

Ucapan terima kasih diberikan kepada LPPM Universitas Pasir Pengaraian dan DRPM Kementerian Riset Teknologi dan Pendidikan Tinggi yang telah memberikan kontribusi dalam pelaksanaan penelitian ini sehingga dapat terlaksana dengan baik.

\section{DAFTAR PUSTAKA}

Ebit Rusali, 2019, Media Bangun Ruang Bambu Untuk Meningkatkan Hasil Belajar Matematika, Jurnal Ilmu Pendidikan Indonesia, 7 (1) 17 - 24;

Herman, 2012, Pengembangan Perangkat Pembelajaran Model Pengajaran Langsung Untuk Mengajarkan Materi Kesetimbangan Benda Tegar, Jurnal Sains dan Pendidikan Fisika, 8 (1): 1-11;

Hohenwarter, M. \& Fuchs, K, 2004. Combination of Dynamic Geometry, Algebra, and Calculus in the Software System Geogebra, Tersedia, 
Jurnal IImu Pendidikan Indonesia 8 (1) : 46 - $55 \mid 55$

www.geogebra.org/publications/pec s_2004.pdf;

Irawati.H dan Saifuddin.F, 2018, Analisis Kebutuhan Pengembangan Bahan Ajar Mata Kuliah Pengantar Profesi Guru Biologi di Pendidikan Biologi Universitas Ahmad Dahlan Yogyakarta. Bio-Pegagogi: Jurnal Pembelajaran Biologi. 7(2) 48-51;

Fitriyah. D. N, Santoso.H, dan Suryadinata.N, 2018, Bahan Ajar Transformasi Geometri Berbasis Discovery Learning melalui Pendekatan Etno Matematika. Jurnal Elemen, 4(2): 145-158;

Setiawati, N. 2014, Kedudukan dan Pemanfaatan Teknologi Informasi dan Komunikasi dalam Pembelajaran Matematika sebagai Implementasi Kurikulum 2013. Prosiding Seminar Nasional Pendidikan Matematika Program Pascasarjana STKIP Siliwangi Bandung;
Sinaga, B. 2007, Pengembangan Model pembelajaran Matematika Berdasarkan Masalah Berbasis Budaya Batak (PBMB3), Disertasi. Tidak diterbitkan, Surabaya: Program Pascasarjana UNESA Surabaya;

Widiyanto, 2019, Perhatian Orang Tua dan Penguasaan Materi Prasyarat Terhadap Belajar Matematika, Jurnal Ilmu Pendidikan Indonesia, 7 (1) $45-56$;

Yuliani, K dan Saragih, S, 2015, The Development of Learning Devices Based Guided Discovery Model to Improve Understanding Concept and Critical Thinking Mathematically Ability of Students at Islamic Junior High School of Medan. Journal of Education and Practice.6 (24) 116 128. 